\title{
Eleştirel Düşünme Becerisi Öğretim Programı Tasarısının Öğrencilerin Yansıtıcı Düşünme Becerilerine Etkisi
}

\section{The Effect of Curriculum Design of Critical Thinking on Students' Reflective Thinking Skills}

\author{
Eray EĞMİR*
}

\author{
Gürbüz OCAK**
}

Received: 20 August 2017

Accepted: 20 April 2018

\begin{abstract}
The aim of this study is to determine the effect of curriculum design of critical thinking skill that was developed by researchers on reflective thinking skills of 5th grade students. In the research process, curriculum design of critical thinking skill was implemented by a skill-based approach and the data which is needed was obtained by quasi-experimental design. The study group of this research consists of two fifth grade classrooms in two secondary schools located in Afyonkarahisar city center in 2015-2016 academic years. The "Reflective Thinking Scale" developed by Yildırım (2012) was used to measure the reflective thinking skills of the students. As a result of the analysis of data, gain scores that were obtained from reflective thinking scale of experimental group indicated a statistically significant difference. In addition to this gain scores that were obtained from reflective thinking skill test of experimental group indicate a statistically significant difference according to daily time spent on computer, tablet and smart phone, purpose of using internet variables. Contrary to this, gain scores did not indicate a statistically significant difference according to gender, socio-economic level, number of books read in a month and participation in extracurricular activities.
\end{abstract}

Keywords: critical thinking, reflective thinking, curriculum design.

ÖZ: $\mathrm{Bu}$ çalışmanın amacı; araştırmacılar tarafından geliştirilen eleştirel düşünme becerisi öğretim program tasarısının, 5. sınıf öğrencilerinin yansıtıcı düşünme becerileri üzerindeki etkisini belirlemektir. Araştırma sürecinde eleştirel düşünme becerisi öğretim program tasarısı öğrencilere beceri temelli bir yaklaşımla uygulanmış ve araştırmada ihtiyaç duyulan veriler yarı deneysel desen ile elde edilmiştir. Araştırmanın çalışma grubunu 2015-2016 eğitim-öğretim yılında Afyonkarahisar il merkezinde bulunan iki ortaokuldaki iki adet beşinci sınıf oluşturmuştur. Öğrencilerin yansıtıcı düşünme becerilerini ölçmek için Yıldırım (2012) tarafından geliştirilen "Yansıtıcı Düşünme Ölçeği” kullanılmıştır. Araştırma sonucunda deney grubunun yansıtıcı düşünme ölçeğinden elde ettiği erişi puanlarının anlamlı olarak farklılaştığı belirlenmiştir. Buna ek olarak deney grubundaki öğrencilerin beceri temelli eleştirel düşünme öğretimi sürecindeki yansıtıcı düşünme erişi puanları bilgisayar, tablet ve akıllı telefon başında geçirilen günlük zaman ve interneti kullanma amacı değişkenlerine göre anlamlı farklılık gösterirken, cinsiyet, sosyoekonomik düzey, bir ayda okunan kitap sayısı, TV başında geçirilen günlük zaman ve ders dışı etkinliklere katılım durumu değişkenlerine göre anlamlı bir farklılık göstermemiştir.

Anahtar kelimeler: eleştirel düşünme, yansıtıcı düşünme, program tasarısı.

\footnotetext{
* Corresponding Author: Asst. Prof. Dr., Afyon Kocatepe University, Afyonkarahisar, Turkey, eegmir@aku.edu.tr

** Prof. Dr., Afyon Kocatepe University, Afyonkarahisar, Turkey, gocak@aku.edu.tr
}

\section{Citation Information}

Eğmir, E. \& Ocak, G. (2018). Eleştirel düşünme becerisi öğretim programı tasarısının öğrencilerin yansıtıcı düşünme becerilerine etkisi. Kuramsal Eğitimbilim Dergisi [Journal of Theoretical Educational Science], 11(3), 431-456. 


\section{Giriş}

Düşünme becerisi insanoğlunu birlikte yaşadığı tüm varlıklardan ayırt eden belirgin bir özelliktir. Düşünme eylemi aracılığıyla insanoğlu hem kendi yaşantısına hem de bu yaşantıyı sürdürdüğü çevreye, durum ve koşullara etki etme ve bunları değiştirme imkânına sahip olmaktadır. İnsanoğlu düşünme ile anlamlandırmakta, sorgulamakta, üretimde bulunmakta, iletişim kurmakta, geçmişini bilmekte, umut etmekte, geleceğini tasarlamakta yani kısacası hayatını kontrol etmektedir. Düşünme eyleminin insan hayatında oynadığı bu önemli rol, onu üzerinde çokça konuşulan, tartışılan ve araştırılan bir olgu haline getirmiştir. Bu sebeple düşünme eylemi hem genel anlamda açıklanmaya hem de farklı bilim dallarının bağlamları içerisinde anlamlandırılmaya çalışılmaktadır.

Genel anlamda düşünme, içinde bulunulan koşulları anlamlandırabilmek için gerçekleştirilen aktif, amaca yönelik, organize bir bilişsel süreç olarak tanımlanabilir (Kurnaz, 2013). Yani düşünme insanın yaşamı boyunca edindiği deneyimlere yönelik sürdürdüğü bir inceleme faaliyetidir. Bu inceleme sonucu insan anlama, karar verme, plan yapma, problem çözme, yargıda bulunma veya eyleme geçme davranışlarından birini sergiler. $\mathrm{Bu}$ yönüyle düşünme hem bir süreci hem de bu sürecin sonunda ulaşılması amaçlanan bir ürünü işaret etmektedir

Eylemlerimizin düşüncelerimize bağlı olduğu düşünülürse doğru olanı yapmanın yolu bu fikir ve düşünceleri kritik etmekten geçer. Böylece karşılaştığımız çıkarımları sorgulamadan kabul etmeme ve bizi bahsedilen şeyi yapmaya veya inanmaya ikna edebilecek kadar iyi bir sebebe dayanıp dayanmadığını inceleyebilme şansı elde edilecektir (Epstein \& Kernberger, 2006). İşte eleştirel düşünme de çok fazla bilginin veya bizi etkilemek isteyen birçok kişinin bulunduğu bir dünyaya karşı girişilen bir savunmadir.

Eleştirel düşünme en genel haliyle ifadelerin mantıklılık düzeyini, geçerliliğini veya doğruluğunu; ya da bir sonucun ne ölçüde makul veya kanıtla doğrulanmış olduğunu değerlendirmektir (Paul, 1990; aktaran, Beyer, 1995). Eleştirel düşünme özyönelimli, öz-disiplinli ve kendi kendini düzelten bir düşünmedir. Düşünmeye ilişkin uygun standartlar belirlenmesini ve bunların duyarlı biçimde uygulanmasını içerir. Eleştirel düşünmenin nihai hedefi bir kişinin düşünmeyi öğrenmesi, düşünce işlem ve süreçleri üzerinde kontrol sağlaması ve bu süreci olumsuz etkileyecek tutumları terk etmesidir (Paul \& Elder, 2013).

Eleştirel düşünmenin tanımı ve yapılan açıklamalar 1şığında, eleştirel bir düşünürün ne tür eğilim ve becerilere sahip olduğu farklı düşünürler tarafından listelenmiştir. $\mathrm{Bu}$ beceri ve özelliklerin net biçimde ifade edilmesi, düşünürler tarafından eleştirel düşünmenin bağlamına ilişkin açık bir anlayışı ortaya koyması bakımından önemlidir.

Beyer (1995), eleştirel bir düşünürün soru, problem veya iddiayı açıkça ifade edebilme, öne sürülen iddiaları destekleyen veya desteklemeyen neden ve kanıtları araştırma ve sunma, yargılarını dogma ve arzular değil amaç, kanıt ve sonuçlar 
temelinde oluşturma, ön bilgileri kullanma ve yeterli kanıt bulunana kadar yargıda bulunmayı erteleme becerilerini göstermesi gerektiğini ifade etmiştir.

Pascarella ve Terenzini (1991; aktaran, Baker, Rudd \& Pomeroy, 2001) ise eleştirel düşünen bir bireyin şu becerilerin tümüne veya bir kısmına sahip olduğunu ifade etmektedir; bir yargıdaki temel noktaları ve varsayımları belirleme, önemli ilişkileri fark etme, eldeki veriler veya bilgilerden hareketle sonuçlar ortaya koyma, düşünmenin üzerine bina edildiği veriler bakımından sonuçların uygun bir durum gösterip göstermediğini yorumlama, kanıtı veya otoriteyi sorgulama.

Ruggerio (2011: 20-21) eleştirel düşünürlerin sahip oldukları özellikleri şu şekilde sıralamıştır:

- Kendilerine karşı dürüsttürler, bilmediklerini kabul ederler, sınırlarının farkındadırlar, kendi hatalarına karşı çok dikkatlidirler.

- Problemleri ve ihtilaflı konuları heyecanlı zorluklar olarak kabul ederler.

- Anlamak için yoğun çaba gösterirler, meraklarını canlı tutarlar, karmaşa karşısında sabırlı kalırlar ve karmaşanın üstesinden gelmek için zaman harcamaya hazırdırlar.

- Kişisel tercihleri ve kanıt üzerindeki kalıp yargıları reddederler, kanıt yetersizse yargıda bulunmayı ertelerler. Yeni kanıtlar hata verdiğinde yargılarını revize ederler.

- Diğer insanların fikirleri ile ilgilenirler, diğer kişiyle aynı fikirde olmasa bile katılımcı okuma ve dinlemeye isteklidirler,

- Uç görüşlerin (tutucu veya liberal) nadiren doğru olduğunun farkındadırlar, bu sebeple bunlardan kaçınırlar, tarafsız hareket ederler ve dengeli bir görüşü ararlar.

- Kendilerine hâkim olurlar, duyguları tarafindan kontrol edilmektense, duygularını kontrol ederler ve hareket etmeden önce düşünürler.

Paul de (1990) eleştirel düşünme ile becerilerin ilişkisini vurgulamış ve yüksek algılı ve düşük algılı eleştirel düşünme şeklinde bir ayrıma gitmiştir. Paul (1990)'a göre eleştirel düşünme entelektüel cesaret ve tevazu ile kendine ilişkin derin bir bilmeyi içerir. Ona göre farklı dünya görüşüne sahip kimselerle iletişim kurmak ve bu açılardan olaylara yaklaşmak eleştirel düşünme için anahtar bir kavramdır ki böylece birey büyük resmi görebilir. Paul (1990) için eleştirel düşünme, bir konu veya bilgi birimi üzerinde hüküm verirken yalnızca kendisinin veya içerisinde bulunduğu sosyal sınıfın bakış açısından hareket etmek anlamına gelen egosantrik ve sosyosantrik düşünme biçimini alt etmenin bir yoludur (aktaran, Mason, 2008).

Eleştirel düşünme öğretiminin önemi ve bu öğretime duyulan ihtiyaç, tüm araştırmacılar ve ülke eğitim sistemleri tarafından fark edilmiştir. Bunun yanı sıra eleştirel düşünme öğretiminin nasıl gerçekleştirileceği noktasında farklı yaklaşımlar mevcuttur. Alanyazına bakıldığında eleştirel düşünmenin öğretimine ilişkin dört temel yaklaşım olduğu gözlemlenmektedir (Ennis, 1989): 
a. Konu Tabanlı Öğretim Yaklaşımı (Infusion): $\mathrm{Bu}$ yaklaşımda eleştirel düşünme prensipleri ile içeriğin öğretimi beraber yürümektedir. Eleştirel düşünme öğretimi içerik öğretiminin içine derin ve dikkatli bir biçimde yerleştirilmiştir ve öğrenciler konunun öğrenimi esnasında eleştirel düşünmeyi kullanmaları noktasında cesaretlendirilmektedir.

b. İçerik Temelli Öğretim Yaklaşımı (Immersion): Bu yaklaşımda içerik ve eleştirel düşünmenin ilke ve kuralları birleştirilmekte ve öğrenciler içerik öğrenimi esnasında eleştirel düşünmeye teşvik edilmektedirler. Bu yaklaşımda ön planda içerik öğretimi yer almakta ve eleştirel düşünmeye dair genel prensipler açık olarak ifade edilmemektedir.

c. Beceri Temelli Öğretim Yaklaşımı (Genel Yaklaşım): Bu yaklaşımda eleştirel düşünme öğretimi bir içeriğe bağlı olmaksızın ayrı bir disiplin gibi temellendirilerek gerçekleştirilir. Eleştirel düşünmenin bileşenleri, standartları ve eleştirel düşünmeye ilişkin beceriler temelinde yapılandırılan bir içerik ile öğrencilere eleştirel düşünme becerisi ve eğilimi kazandırılmaya çalışılır. Genel yaklaşımda genellikle yerel ya da ulusal politik konular, okul kantinindeki problemler veya çevre sorunları gibi içerikler mevcuttur. Ancak bu yaklaşım bir içerik olmasını gerektirmez.

d. Karma Öğretim Yaklaşımı: Bu yaklaşım genel yaklaşımla konu tabanlı veya içerik temelli yaklaşımın bir birleşiminden oluşmaktadır. Bu yaklaşımda eleştirel düşünmenin genel prensiplerini öğretmeyi hedefleyen ayrı bir kurs bulunmaktadır; ancak öğrenciler, içerik temelli bir eleştirel düşünme öğretimine de katılırlar.

Birey eleştirel düşünürken arzu edilen bir sonucun olasılığını artıran bilişsel becerileri veya stratejileri kullanır. Amaçlı, mantıklı ve hedefe dönük bir düşünme biçimi olan eleştirel düşünme esnasında birey çıkarımlar oluşturur, olasılıkları hesaplar ve bunlar 1şı̆̆ında belirli bir bağlam içerisinde kararlar verir (Halpern, 1996). Bununla birlikte yansıtıcı düşünme sürecinde birey bir eylemi gerçekleştirirken veya gerçekleştirdikten sonra edindiği deneyimler üzerine eleştirel biçimde düşünür, problemi belirler ve çözer, bunun sonucunda da geleceğe yönelik düşünceleri yeniden yapilandirır (Moon, 2008).

Eleştirel düşünme için temel bir önkoşul bireyin kendi düşünme sürecinin farkında olması, bu sürecin sorumluluğunu alması ve düşünmesini izlemek ve değerlendirmek için mantıklı bir ölçüt geliştirebilmesidir (Elder \& Paul, 2004). Yani yansıtıcı düşünme, eleştirel düşünme sürecini yürüten bir bireyin, bu sürecin niteliğini artırması ve istenen sonuca ulaşma olasılığını yükseltmesi için başvurması gereken öncelikli becerilerdendir. Yansıtıcı düşünme ise bu süreçte gerçekleşenlere dönük incelemeler yapmak için takınılan eleştirel bir bakıştır. Bu yolla birey zihinsel anlamda olgunlaşmamış bir düzeyden en üst düzey tecrübe sahibi olduğu seviyeye kadarki gelişimini ve öz bilgi edinme ve öğrenme süreçlerini analiz etme ve değerlendirme imkânı edinecektir (Moon, 2008).

$\mathrm{Bu}$ açıdan bakıldığında eleştirel düşünme ve yansıtıcı düşünme kimi zaman aynı anlamda da kullanılabilen, birbiriyle iç içe düşünme becerileridir ve bireyin yansıtıcı düşünebilmesi için öncelikle eleştirel düşünebilmesi gerekmektedir (Elaldı, 2013; Tican, 2013). Çünkü kendi deneyimleri üzerine yansıtma yapan bir birey bu deneyimlere 
ilişkin tüm olgu ve süreçleri eleştirel bir bakışla inceleyecek ve bu olgu ve süreçleri analiz ederek bunlar hakkında incelenmiş yargılara ulaşacaktır. Ünver (2003) de yansıtıcı düşünen birinin aynı zamanda eleştirel düşünebileceğini belirtmiştir.

Yansıtıcı düşünme bireyin edindiği deneyimler, bu deneyimlerin analizi ve bu analizin sonuçlarının ifade edilmesini kapsayan bir süreçtir (Rodgers, 2002). Yansitıcı düşünme bir inanış ve varsayılan bilgi biçiminin onu destekleyen temeller ve üretmesi muhtemel sonuçlar 1şığında aktif, ısrarcı ve dikkatli bir biçimde ele alınmasıdır. Yansıtıcı düşünme eğitim-öğretim ortamı bağlamında, mantıklı tercihler yapma ve bu tercihler için uygun bir sorumluluk yüklenme yetisi gerektiren eğitsel durumlar için kullanılan bir düşünme becerisidir (Dewey, 1933; aktaran, Ross, 1989). Bu süreçte öğrenci eğitim uygulamasına ilişkin felsefeyi, stratejiyi, öğretme ve öğrenme yöntemini, materyalleri ve eğitimsel sonuçları sorgular ve bu unsurları analiz ederek olumlu ve olumsuz yönleri ortaya çıkarmayı hedefler.

Yansıtıcı düşünme bireyin kendisi tarafında yönlendirilen ve kendine özgü düşünsel ürünler oluşturduğu yapılandırmacı bir süreçtir. Yansıtıcı düşünme ile birey bir bilgi birimi veya konu hakkındaki fikirleri ardışık bir şekilde ilişkilendirerek bir sonuca varır. Yani bu tarz düşünmede bir konuya ilişkin görüşler basit bir şekilde listelenmez (Gelter, 2003).

Dewey $(1933,1938)$ tarafından, yansıtıcı düşünme ve eleştirel düşünme ifadeleri bazen birbirlerinin yerine kullanılmaktadır (aktaran, King \& Kitchener, 1994). Bunun yanında eleştirel düşünme ile yansıtıcı düşünme arasında kapsam yönünden bir farklılık mevcuttur. Eleştirel düşünme bireyin karşılaştığı tüm olay, olgu, fikir veya görüşlere karşı ölçütlere dayalı olarak bir değerlendirme yapma faaliyetidir. Yansıtıcı düşünme ise bireyin kendi deneyimleri üzerine eleştirel düşünmesi ile ilişkilidir. Bu bilgiler 1şı̆̆ında bireyin yansıtıcı düşünmek için öncelikle eleştirel düşünme becerisine sahip olması gerektiği ve eleştirel düşünme becerisinin yansitıcı düşünme becerisini sergileme açısından kritik bir işleve sahip olduğu söylenebilir. $\mathrm{Bu}$ nedenle eleştirel düşünme becerisini geliştirmeye dönük eğitimsel süreçlerin bireyin yansıtıcı düşünme becerisinde de olumlu bir değişim göstereceği beklenmektedir.

Ennis (1985), eleştirel düşünmeyi, ne yapılacağına ve neye inanılacağına karar vermeye odaklı mantıklı ve yansıtıcı düşünme olarak tanımlamış, eleştirel düşünmede pratiklik, yansıtıcılık, kıyaslanabilirlik, amaç ve eylem olmak üzere beş anahtar niteliğin olduğunu ve bu niteliklerin birleşimiyle eleştirel düşünmenin tanımının yapılabileceğini ileri sürmüştür (Semerci, 2000). Böylece iki yönlü bir ilişki olarak yansıtıcı düşünmenin de eleştirel düşünmeyi geliştirdiği düşünülmektedir. Yansıtıcı düşünme, ne olup bittiği ile ilgili analizler yapma ve yargıya varma süreçlerini özellikle ifade eden eleştirel düşünmenin bir parçasıdır (Choy \& Oo, 2012). Yansıtıcı düşünen bir öğrenci; inceleme, açıklama, örgütleme, mantık yürütme, hipotez oluşturma, tahmin etme, analiz, sentez, değerlendirme, genelleme becerilerini kullanarak eleştirel düşünür (Wilson \& Jan, 1993).

Bu çalışmada uygulanan beceri temelli eleştirel düşünme becerisi öğretiminin 5 . sınıf öğrencilerinin yansıtıcı düşünme becerilerinde anlamlı bir faklılığa neden olup olmadığının belirlenmesi araştırmanın temel problemidir. Bununla birlikte 5. sınıf 
öğrencilerinin beceri temelli eleştirel düşünme becerisi öğretimi sürecinde elde ettikleri yansitıcı düşünme beceri düzeylerinin cinsiyet, sosyoekonomik düzey, bir ayda okunan kitap sayısı, TV başında günlük geçirilen zaman, bilgisayar, tablet ve akıllı telefon başında günlük geçirilen zaman, internet kullanma amacı, ders dışı etkinliklere (sanat, müzik, spor vb.) katılım durumu değişkenlerine göre anlamlı olarak farklılaşıp farklılaşmadığının tespit edilmesi ise araştırmanın alt problemi olarak belirlenmiştir.

Çalışma sonucunda eleştirel düşünme ile yansıtıcı düşünme arasındaki ilişkiye dair alanyazına bir katkı yapılması amaçlanmıştır. İleri seviye düşünme becerileri arasındaki ilişkiyi hem teorik hem de uygulamaya dönük bir bakışla ortaya koymanın, bu becerilerin daha etkili biçimde öğretilmesini sağlayacağı düşünülmektedir. Özellikle günümüz eğitim sistemleri için önemli olan ileri seviye düşünme becerilerinin öğrencilere kazandırılması hedefi, bu becerilerin bağlamını ve ilişkilerini net olarak ortaya koyacak çalışmalar ile daha ulaşılabilir hale gelecektir. Yansitıcı düşünmenin eleştirel bir bakışa sahip olan bireylerde ne düzeyde gerçekleştiğinin belirlenmesiyle hem yansıtıcı düşünmenin diğer bir ileri seviye düşünme becerisiyle ilişkisinin ortaya konulmasına katkı sağlanacak hem de yansıtıcı düşünmeyi geliştirmek adına bir yol önerilmiş olacaktır.

\section{Yöntem}

Araştırmada deneysel desen kullanılmıştır. Deneysel araştırmalar araştırmacı tarafından oluşturulan farkların bağımlı değişken üzerindeki etkisini test etmeye yönelik çalışmalardır. Deneysel desenlerde temel amaç değişkenler arasında oluşturulan neden sonuç ilişkisini test etmektir. Bu çalışmada da deneysel desen aracılığıyla yansıtıcı düşünme beceri düzeyi ile eleştirel düşünme beceri düzeyi arasındaki ilişkiyi belirlemek amaçlanmıştır (Büyüköztürk, Kılıç Çakmak, Akgün, Karadeniz, \& Demirel, 2013).

$\mathrm{Bu}$ araştırmada tek grup öntest-sontest desen kullanılmıştır. Bu desende deneysel işlemin etkisi tek bir grup üzerinde yapılan çalışmayla test edilir. Deneklerin bağımlı değişkene ilişkin ölçümleri uygulama öncesinde ön test, sonrasında son test olarak seçkisizlik ve eşleştirme olmadan aynı denekler ve aynı ölçme araçları kullanılarak elde edilir (Büyüköztürk ve diğerleri, 2013). Uygulama öncesinde deney grubuna yansitıcı düşünme ölçeği uygulanmıştır. İşlem sürecinde deney grubuna eleştirel düşünme becerisi öğretim programı tasarısı doğrultusunda araştırmacılar tarafından hazırlanan beceri temelli öğretim uygulanmıştır.

$\mathrm{Bu}$ yaklaşımda temel amaç öğrencilere okul dışındaki bağlamlarda eleştirel düşünmeyi öğretmektir. $\mathrm{Bu}$ nedenle öğrencilerin günlük hayatta karşılaştıkları problemler içerik olarak uygulama sürecinde incelenmiştir. Örnek olarak öğrencinin "verilen bir durumdaki problemin farkına varır" kazanımına dönük yapılan etkinlikte bir öğrencinin bir ödev hazırlarken karşılaştı̆̆ı durumlar veya "ilişkili ve ilişkili olmayan bilgi ve nedenleri ayırt eder" kazanımında ise bir mısır cipsi alırken hangi bilgi ve ölçütleri kullanmalarının daha uygun olacağına dair uygulamalar yapılmıştır. Uygulama sonrasında ise deney grubuna yansıtıcı düşünme ölçeği bir kez daha uygulanmıştır. 


\section{Çalışma Grubu}

$\mathrm{Bu}$ araştırmanın çalışma grubunu 2015-2016 eğitim-öğretim y1lında Afyonkarahisar il merkezinde bulunan iki ortaokuldaki toplam iki adet beşinci sınıf oluşturmaktadır. Sosyoekonomik düzey değişkeninin yansitıcı düşünme becerisi üzerindeki etkisini belirlemek amacıyla uygulamanın yapıldığı iki okul Afyonkarahisar ilinin sosyoekonomik düzey olarak farklılaşan iki bölgesinden seçilmiştir. Okulların sosyoekonomik düzeyine ilişkin bilgi, Afyonkarahisar İl Milli Eğitim Müdürlüğü’nden edinilmiştir. Okullarından seçiminde uygun örnekleme tekniği kullanılmıştır.

Okullardan ilki yüksek ve orta sosyoekonomik düzeye sahip ailelerin çocuklarından oluşmakta olan bir ortaokuldur. Okul hem öğretmen kadrosu hem de öğretimsel firsatlara erişim açısından ilin en gözde ortaokullarından birisidir. Bununla birlikte fiziksel imkânları da iyi durumdadır. Diğer okul ise şehir merkezine daha uzakta olmakla birlikte alt ve orta sosyoekonomik düzeye sahip ailelerin çocuklarının devam ettiği bir okuldur. Okulun fiziksel koşulları oldukça kötüdür. Öğrencilerin birçok teknolojik ve öğretimsel imkânlara erişemediği gözlemlenen okulda öğrencilerin öğretime ilişkin ve motivasyonunun gayet düşük olduğu ifade edilebilir. Çalışmada farklı sosyoekonomik düzeye sahip okullar üzerinde uygulama yapılmasının nedeni eleştirel düşünme öğretim sürecinde sosyoekonomik düzey değişkeninin etkisini ortaya çıkarmak ve farklı düzeydeki okul ve öğrencilerden elde edilen verilerle bir veri çeşitlemesi yapılarak daha zengin çıktılara ulaşmaktır.

Uygulama yapılacak sınıflar ise okullardan seçkisiz olarak seçilmiştir. Yüksek sosyoekonomik düzeye sahip okuldaki deney grubu 10 erkek 16 kız öğrenci olmak üzere toplam 26 öğrenciden oluşmaktadır. Düşük sosyoekonomik düzeye sahip okuldaki deney grubu ise tümü erkek öğrenci olmak üzere 22 öğrenciden oluşmaktadır. Sosyoekonomik düzey değişkenine dair analiz dışındaki tüm analizlerde bu iki farklı grup tek grup olarak dikkate alınmıştır.

\section{Veri Toplama Aracı}

Öğrencilerin yansıtıcı düşünme becerilerini ölçmek için Yıldırım (2012) tarafından "Bilimsel Süreç Becerileri Etkinliklerinin İlköğretim 7. Sınıf Öğrencilerinin Yansıtıcı Düşünmelerine Etkisi” adlı yüksek lisans tezi kapsamında geliştirilen "Yansıtıcı Düşünme Ölçeği” kullanılmıştır. Ölçek 5'li likert tipi bir ölçek olup 17 maddeden oluşmaktadır. Ölçek tek faktörlüdür ve ölçekteki maddeler "1. Hiç katılmıyorum, 2. Katılmıyorum, 3. Kararsızım, 4. Katıliyorum, 5. Tamamen katılıyorum" biçiminde derecelendirilmiştir. Ölçeği geliştirme çalışmaları, Denizli iline yakın ilçelerin farklı sosyoekonomik bölgelerinden oransız eleman örnekleme seçme yöntemiyle belirlenen altı ilköğretim okulunda 6., 7. ve 8. sınıflarda öğrenim görmekte olan toplam 320 öğrenciden elde edilen verilerle yapılmıştır (Yıldırım, 2012). Araştırmacı ölçeğin madde-toplam korelasyonlarının 0.49 ile 0.63 arasında değişmekte olduğunu belirtmiştir. Ayrıca madde faktör yükleri .47 ile .64 arasında değişmektedir. Tek faktörlü olduğu belirtilen ölçekteki maddelerden birkaçı şu şekildedir:

- Alternatif yöntemler ve bakış açıları üzerinde düşünürüm. 
- Arkadaşlarımın çözüm yollarını sorgulayarak daha iyi bir yol bulmaya çalışırım.

- Çözüm yollarımı tekrar tekrar değerlendirip bir sonraki problemi daha iyi çözmeye çalışırım.

- Bir problemi çözdügüümde yaptığım işlemleri tekrar inceler, değerlendiririm

Hem madde hem de faktör temelinde elde edilen madde-test korelasyon katsayılarının negatif, sıfır ya da sıfıra yakın bulunmadığından aracın iç tutarlılığının yüksek ve dolayısıyla yapı geçerliğinin var olduğu araştırmacı tarafindan ifade edilmiştir. Ölçme aracının Cronbach $\alpha$ güvenilirlik katsayısı ise .86 bulunmuştur. $\mathrm{Bu}$ çalışmada yansitıcı düşünme ölçeğinin ön uygulamasından elde edilen Cronbach $\alpha$ güvenilirlik katsayısı .97 , son uygulamasından elde edilen Cronbach $\alpha$ güvenilirlik katsayısı ise .80 bulunmuştur.

Çalışma grubuna 20 saatlik uygulama öncesinde ve sonrasında ölçme aracı uygulanmış ve uygulama öncesi ve sonrasında yansıtıcı düşünme becerileri arasında anlamlı bir fark olup olmadığını belirlemek amacıyla Wilcoxon İşaretli Sıralar testi yapılmıştır. Bununla birlikte deney grubundaki öğrencilerin beceri temelli eleştirel düşünme becerisi öğretimi sürecinde elde ettikleri yansıtıcı düşünme erişi puanlarının cinsiyet, sosyoekonomik düzey, TV başında günlük geçirilen zaman, bilgisayar, tablet ve akıllı telefon başında günlük geçirilen zaman, interneti kullanma amacı ve ders dişı etkinliklere (sanat, müzik, spor vb.) katılım durumu değişkenlerine göre anlamlı olarak farklılaşıp farklılaşmadığını belirlemek için "Mann Whitney-U" testi yapılmıştır. yansıtıcı düşünme becerisinin bir ayda okunan kitap sayısı değişkenine göre anlamlı olarak farklılaşıp farklılaşmadığını belirlemek için ise "Kruskal Wallis" testi yapılmıştır.

Ölçme aracından elde edilen veriler istatistik programı aracılığıyla bilgisayar ortamında analiz edilmiştir. Tüm analizlerde anlamlılık düzeyi olarak .05 kullanılmıştır.

\section{Eleştirel Düşünme Öğretim Programı ve Uygulanması}

Eleştirel düşünme öğretim programı araştırmacı tarafından geliştirilen ve 18 kazanımdan oluşan bir programdır. Programın geliştirilmesi sürecinde eleştirel düşünme becerisi göz önüne alındığında İlerlemecilik felsefesini yansıtacak bir öğretim programı olması düşünülmüş ve buna uygun olarak program tasarım yaklaşımlarından "çocuk merkezli tasarım" benimsenmiştir.

Programın hedefleri belirlenirken alanyazında eleştirel düşünme üzerine çalışan uzmanların belirledikleri hedefler incelenmiş ve bu hedeflerden programın temelleri göz önüne alınarak araştırmaya uygun olanlar seçilerek bir hedef havuzu oluşturulmuştur. Bu hedef havuzu oluşturulurken Haladyna'nın 1997 yılında geliştirdiği taksonomi temel alınmıştır. $\mathrm{Bu}$ taksonomi yüksek düzeyli düşünme becerilerini dikkate alarak tek boyutlu bir sınıflama yapmıştır. Bu sınıflamada sırasıyla anlama, problem çözme, eleştirel düşünme ve yaratıcılık olmak üzere dört basamak yer almaktadır (Yüksel, 2007).

$\mathrm{Bu}$ aşamada ayrica Afyonkarahisar il merkezinde görev yapan ve maksimum çeşitlilik yöntemiyle seçilen 19 öğretmen ile dört sorudan oluşan ve eleştirel düşünme 
ve öğretimine ilişkin ihtiyacı konu edinen yarı yapılandırılmış bir görüşme formu yardımıyla görüşme yapılmış ve veriler içerik analizi yöntemi ile analiz edilmiştir. Öğretmen grubu 11 erkek sekiz kadın öğretmenden oluşmaktadır. Öğretmenlerin 14'ü ilk ve ortaokul, dört tanesi lise, biri ise okul öncesi kademede görev yapmaktadır. Öğretmenlerin altı tanesi sınıf, dört tanesi fen bilimleri, iki tanesi biyoloji, bir tanesi sosyal bilgiler, bir tanesi İngilizce, bir tanesi okul öncesi, bir tanesi elektrik, bir tanesi özel öğretim, bir tanesi fizik ve bir tanesi matematik branşında görev yapmaktadır.

$\mathrm{Bu}$ çalışmada nitel verilerin kodlanması analizinde bağımsız bir eş gözlemci rol almıştır. Bu noktada kodlamalara son hali iki gözlemcinin ayrı ayrı yaptığı kodlamalar sonrasında karar verilmiştir. Bu noktada Miles ve Huberman (1994)'ın eş gözlemci güvenilirliğine ilişkin ortaya koymuş oldukları formül kullanılmıştır. Formül şu şekildedir:

\section{Güvenilirlik= Üzerinde Uzlaşılan Kodlamaların Sayısı/Tüm Kodlamaların}

\section{Saylst}

$\mathrm{Bu}$ formüle göre eş gözlemciye ilişkin güvenilirlik .84 bulunmuştur. Miles ve Huberman (1994) .70 ve üzerindeki değerlerin güvenilir sonuçlara işaret ettiğini ifade etmiştir.

Ayrıca yine Afyonkarahisar il merkezinde görev yapan ve kolaylı örnekleme metodu ile belirlenen 30 öğretmene "Eleştirel Düşünmeye İlişkin İhtiyaç Belirleme Formu" uygulanmıştır. Form öğretmenlerin oluşturulan hedef havuzundaki hedeflerin önem derecesine ilişkin algılarını belirlemek amacıyla hazırlanmış beş dereceli bir formdur. Form 18 adet kazanım ifadesinden oluşmaktadır ve formda "en az önemli", "kısmen önemli", “önemli”, “çok önemli” ve "son derece önemli” ş̧eklinde bir derecelendirme mevcuttur.

$\mathrm{Bu}$ iki veri toplama sürecinden elde edilen veriler doğrultusunda, alanyazın taraması sonucu Ennis (2011) ve Facione (1990)'nin eleştirel düşünme becerileri dikkate alınarak, oluşturulan hedef havuzuna son hali verilmiş ve sonrasında bu hedefler ölçülebilir kazanım ifadelerine dönüştürülmüştür. Bu çalışmada yukarıda belirtilen bilgilere ve yapılan araştırmalara dayalı olarak programın kazanımları şu şekilde belirlenmiştir:

1. Verilen bir durumdaki problemi anlar.

a) Verilen bir durumdaki problemin farkına varır

b) Verilen bir durumdaki problemi net biçimde tanımlar

c) Verilen bir durumdaki problemin çözümü için edinilmesi gereken bilgileri belirler

2. Öznel ve nesnel yargı belirten ifadeleri ayırır.

3. Çıkarımları analiz eder.
a) İddia, konu (sorun) ve çıkarım kavramlarının özelliklerini bilir
b) Çıkarımı diğer ifade yollarından ayırt eder
c) Bir çıkarımı oluşturan temel bileşenleri bilir
d) Kesin ve kesin olmayan sonuçları ayırt eder
e) İlişkili ve ilişkili olmayan bilgi ve nedenleri ayırt eder 
f) Belirtilmiş veya belirtilmemiş varsayımları belirler

4. Amaca uygun sorular sorar

5. Çıkarımları değerlendirir

a) Bir çıkarımın gücünü test eder

a. Öncüllerin kabul edilebilirliğini test eder

b. Öncüllerin kendi aralarındaki tutarlılı̆̆ test eder

c. Öncüllerle sonuçlar arasındaki uyuma bakar

d. Belirtilmeyen ancak sonucu değiştirebilecek unsurların farkına varır

b) Diğer bakış açılarını göz önüne alır.

6. Bir kaynağın güvenilirliğini belirler

a) Bir kaynağın güvenilirliğini saptamada kullanılacak ölçütler belirler

b) Ölçütleri, bir kaynağın güvenilirliği saptamada etkin biçimde kullanır

Eleştirel düşünme öğretim programı tasarısının öğrenme yaşantılarının seçiminde öğrenciyi eleştirel düşünmeye sevk edecek, öğrencinin ilgi, motivasyon ve öğrenme sürecine katılım isteğini canlı tutacak, farklı bakış açılarına saygı duymasını teşvik edecek strateji, yöntem ve tekniklerin işe koşulması hedeflenmiştir. Etkinliklerin hazırlanmasından ve bu etkinlikleri uygularken kullanılacak yöntem ve tekniklerin belirlenmesinden sonra düşünme becerileri konusunda çalışmalar yapan iki uzmandan ve bir program geliştirme ve değerlendirme alanı uzmanından görüş alınmış ve bu görüşler doğrultusunda değişiklikler yapılmıştır.

Program içeriğinin oluşturulmasında sorgulama merkezli içerik düzenleme yaklaşımı kullanılmıştır. Sorgulama merkezli içerik düzenleme yaklaşımında öğrencilerin ilgi ve ihtiyaçları önemlidir ve içerik öğrencilerin sorunlarına göre düzenlenir. $\mathrm{Bu}$ yaklaşımda içeriğin öğrencilerin ve toplumun sorunlarıyla ilgili bir yapıda olması amaçlanır. Özellikle ilkokul ve ortaokul çağındaki öğrenciler için içerikte sorgulanacak problem durumlarının bulunması öğrenme ortamına düşünmeye sevk edici bir yapı kazandırmak açısından verimli kılacaktır (Demirel 2009; Karacaoğlu, 2011).

$\mathrm{Bu}$ çalışmada da öğrencilere önce eleştirel düşünme becerisi ve bu beceriyi kullanmaya dönük stratejileri hakkında bilgi verilmiş ve bu stratejileri karşılaştıkları problem durumu üzerinde kullanmaları sağlanmıştır. Bu yaklaşım öğrencinin merakını uyandıran, dikkatini çeken ve kafasında soru işareti oluşturan bir problem durumun öğrenciye sunulması ile başlamıştır. $\mathrm{Bu}$ problem durumunun öğrenciye düşünmesi esnasında alternatifler oluşturabileceği bir yapıda olmasına dikkat edilmiştir. Bu tür sorgulamalar sırasında öğrencilerin sadece becerileri değil, yüksek nitelikli bilgi işleme etkinliklerinde gerekli olan tutumları ve değerleri öğrenmesi de sağlanmaya çalış1lmıştır.

Etkinliklerin öğrencinin o kazanıma dair temel noktaları özümsemesini sağlamaya dönük olarak seçilmesine dikkat edilmiş ayrıca içeriğin güncel olması önemli görülmüştür. Bunun yanı sıra etkinliklerin öğrencinin yaş, gelişim düzeyi ve hazırbulunuşluğuna uygun, ilgi ve ihtiyaçlarını karşılayıcı bir durumda olması öncelenmiştir. $\mathrm{Bu}$ nedenle beşinci sınıf öğrencisinin hayatına yakın örnekler, durumlar 
ve problemler sınıf ortamına taşınarak öğrencilerin bunlar üzerinde etkin biçimde düşünmesi sağlanmaya çalışılmıştır. Etkinliklerin hazırlanmasından sonra düşünme becerileri konusunda çalışmalar yapan iki uzmandan görüş alınmış ve bu görüşler doğrultusunda değişiklikler yapılmıştır.

Kazanımların belirlenmesi ve içeriğin oluşturulmasından sonra öğrencilere bu hedefleri kazandıracak etkinlikler tasarlanmış ve bu 19 etkinlik çalışma grubuna 20 saatlik bir öğretim sürecinde uygulanmıştır. Uygulama öncesindeki bir ders saati sürede öğrencilere eleştirel düşünmenin önemine ve öğretiminin sağlayacağı yararlara ilişkin bir bilgilendirme sunumu yapılmış ve bunun üzerine öğrencilerin eleştirel düşünmeye ilişkin algılarına yönelik kısa bir tartışma yürütülmüştür. Sonrasında ise her etkinlik bir ders saatine karşılık gelecek şekilde etkinlikler gerçekleştirilmiştir.

Program kapsamında temel olarak buluş yoluyla öğretim stratejisi kullanılmıştır. $\mathrm{Bu}$ stratejide odak öğrenciye önceden belirlenmiş olan bilgileri aktarmak değil, öğrencilerin kendi deneyimleri ve düşünmesiyle öğrenebileceği ortamlar oluşturmaktır. $\mathrm{Bu}$ yaklaşım temelde öğrencinin genellemelere kendi çabasıyla, sezerek ulaşmasının sağlandığı öğrenci merkezli bir yaklaşımdır. Buluş yolu belli bir problem veya konu alanı ile ilgili verilerin toplanması, analiz edilmesi ve bütüne ulaşmayı sağlayan öğrenci etkinliğine dayalı bir stratejidir (Şahin, 2015).

$\mathrm{Bu}$ çalışmada eleştirel düşünme becerisinin öğretimi amaçlandığından, bilginin ediniminden bu bilgiden hareketle yargıya ulaşmaya kadar tüm süreçlere dair becerilerin de öğretimi gerçekleştirilmiştir. Bu nedenle işletilecek olan süreç öğrencinin bilgiyi aktif biçimde analiz ettiği ve değerlendirdiği bir süreçtir. Bu yönüyle bilgi birey tarafindan öznel zihinsel süreçler aracılığıyla kişisel bir bilgi formuna döndürülmektedir. Eleştirel düşünme becerisinin öğretimi esnasında bireyin bilgiyle karşılaştığı andan itibaren bilgiye dönük bir akıl yürütme süreci işletmesi ve bu süreçten amaca yönelik yeni bilgiler oluşturması hedeflenmiştir. Bu hedef ve bilgiler 1şığında programın öğrenme yaşantıları seçilip düzenlenirken buluş yoluyla öğretim stratejisi kullanılması kararlaştırılmıştır.

Programın uygulaması esnasında araştırmacı programın bizzat uygulayıcısı konumundadır. Yani eleştirel düşünme programı rehberliğinde oluşturulan derslerde araştırmacı öğretmen görevi görmüştür. Bu noktada programın felsefesi ve yapısı itibariyle öğretmen yalnızca derslerin ilk kısmında ilgili kavram ve olguların tanımı hakkında bilgi vermesi yoluyla merkezde bulunmuştur. Bunun dışında öğrenci öğretim ortamında hep aktif durumdadır. Bunun yanı sıra sürecin başında, uygulama sürecinde ve süreç sonunda tüm ölçme ve değerlendirme eylemleri de araştırmacı tarafından gerçekleştirilmiş̧tir. 


\section{Verilerin Analizi}

Araştırmada ilk olarak çalışma grubundaki öğrencilerin yansıtıcı düşünme erişi puanlarının normallik testi yapılmıştır. Yapılan analizler sonucunda aşağıdaki verilere ulaşılmıştır.

Tablo 1

Çalışma Grubunun Yansıtıcı Düşünme Ölçeği Erişi Puanlarının Normallik Testi Sonuçları

\begin{tabular}{|c|c|c|c|}
\hline & & $\begin{array}{l}\text { Kolmogorov- } \\
\text { Smirnov }\end{array}$ & $\begin{array}{l}\text { Shapiro- } \\
\text { Wilk }\end{array}$ \\
\hline Erişi Puanı & & .002 & .000 \\
\hline \multirow{2}{*}{ Cinsiyet } & Erkek & .001 & .000 \\
\hline & Kadın & .200 & .286 \\
\hline \multirow{2}{*}{ Sosyoekonomik Düzey } & Yüksek & .036 & .021 \\
\hline & Düşük & .019 & .003 \\
\hline \multirow{2}{*}{ TV başında günlük geçirilen zaman } & $0-2$ saat & .003 & .001 \\
\hline & $3-5$ saat & .200 & .035 \\
\hline \multirow{2}{*}{$\begin{array}{l}\text { Bilgisayar, tablet ve akıllı telefon başında } \\
\text { günlük geçirilen zaman }\end{array}$} & $0-2$ saat & .060 & .014 \\
\hline & $3-5$ saat & .200 & .358 \\
\hline \multirow[t]{2}{*}{ İnterneti kullanma amacı } & $\begin{array}{l}\text { Sosyal } \\
\text { Medya/Oyun/Müzik/Video }\end{array}$ & .068 & .005 \\
\hline & Ödev Araştırma & .076 & .018 \\
\hline \multirow{2}{*}{ Ders dışı etkinliklere katılım } & Evet & .029 & .004 \\
\hline & Hayır & .144 & .038 \\
\hline \multirow{3}{*}{ Bir ayda okunan kitap sayısı } & $0-4$ & .013 & .011 \\
\hline & $5-9$ & .058 & .113 \\
\hline & 10 ve üstü & .045 & .004 \\
\hline
\end{tabular}

Tablo 1'deki veriler incelendiğinde çalışma grubundaki öğrencilerin yansıtıcı düşünme erişi puanlarının normal dağılmadığı belirlenmiştir. Ayrıca çalışma grubundaki öğrencilerin yansıtıcı düşünme erişi puanlarının tüm değişkenlere göre dağılımlarının da normal olmadığı tespit edilmiştir.

Araştırmada çalışma grubu öğrencilerinin uygulama öncesi ve sonrasında yansitıcı düşünme beceri puanları arasında anlamlı bir fark var olup olmadığını belirlemek için normallik testine dayalı olarak Wilcoxon İşaretli Sıralar testi yapılmıştır. Çalışma grubundaki öğrencilerin yansıtıcı düşünme becerisine ilişkin elde ettikleri erişi puanlarının cinsiyet, sosyoekonomik düzey, TV başında günlük geçirilen zaman, bilgisayar, tablet ve akıllı telefon başında günlük geçirilen zaman, interneti kullanma amacı ve ders dışı etkinliklere katılım değişkenlerine göre anlamlı olarak farklılaşıp farklılaşmadığını belirlemek amacıyla Mann Whitney-U testi yapılmıştır. Bir ayda 
okunan kitap sayısı değişkenine göre anlamlı olarak farklılaşıp farklılaşmadığını belirlemek amacıyla ise Kruskal Wallis testi yapılmıştır.

$\mathrm{Bu}$ bölümde verilerden elde edilen bulguların daha sağlıklı değerlendirilmesi açısından bulgular üzerinde etki analizleri yapılmış ve yorumlar bu analizler üzerine bina edilmiştir. Etki büyüklüğü, örneklemden elde edilen sonuçların yokluk hipotezinde ifade edilen beklentilerden ne düzeyde saptığını gösteren istatistiksel değerdir (Cohen, 1994). Etki büyüklüğünün hesaplanmasında en yaygın kullanılanı Cohen tarafindan geliştirilen hesaplama (d) olmakla birlikte, Hedge's d, Glass's $\Delta$ gibi hesaplamalara da literatürde rastlanabilir (Yıldırım \& Yıldırım, 2011). Cohen genel bir öneri olmak üzere, d değerinin 0,2 'den küçük olması durumunda etki büyüklügünün zayıf, 0.5 olması durumunda orta ve 0,8 'den büyük olması durumunda ise kuvvetli olarak tanımlanabileceğini söylemektedir. Ancak, 0,2'lik bir d değerinin bile kuvvetli bir etki olarak ele alınabileceği özel durumların da olabileceği unutulmamalıdır (Cohen, 1988; aktaran, Kılıç, 2014). Çalışma sürecinde elde edilen veriler istatistik programı aracılığıyla bilgisayar ortamında analiz edilmiştir. Tüm analizlerde anlamlılık düzeyi olarak .05 kullanılmıştır.

\section{Bulgular}

Araştırmada ilk olarak çalışma grubundaki öğrencilerin uygulama öncesi ve sonrasında yansıtıcı düşünme becerileri arasında anlamlı bir fark olup olmadığı incelenmiştir. $\mathrm{Bu}$ amaçla yapılan "Wilcoxon İşaretli Sıralar testi”ne ilişkin sonuçlar Tablo 2'de verilmiştir.

Tablo 2

Çalışma Grubunun Öğretim Öncesi ve Sonrası Yansıtıcı Düşünme Ölçeği Puanlarının Wilcoxon Işsaretli Siralar Testi Sonuçları

\begin{tabular}{|c|c|c|c|c|c|}
\hline Sontest-Öntest & $N$ & Sira Ortalaması & Sira Toplamı & $z$ & $p$ \\
\hline Negatif Sıra & 11 & 11.09 & 122.00 & \multirow{3}{*}{-4.67} & \multirow{3}{*}{.00} \\
\hline Pozitif Sura & 36 & 27.94 & 1006.00 & & \\
\hline Eşit & 1 & & & & \\
\hline
\end{tabular}

${ }^{*} p<.05$

Tablo 2'deki veriler incelendiğinde beceri temelli eleştirel düşünme öğretiminin uygulandığı öğrencilerin öğretim öncesi ve sonrasında yansıtıcı düşünme becerisi ölçeğinden aldıkları puanlar anlamlı bir farklılık göstermektedir $(p<.05)$. Fark puanlarının sıra ortalaması ve toplamları dikkate alındığında gözlenen bu farkın pozitif sıralar yani sontest puanı lehinde olduğu görülmektedir. Buna göre beceri temelli eleştirel düşünme öğretimi, çalışma grubu öğrencilerinin yansıtıcı düşünme becerileri üzerinde anlamlı bir farklılığın oluşmasını sağlamıştır. Yapılan etki analizi sonucu etki büyüklüğü 47 bulunmuş ve yapılan öğretimin belirlenen fark üzerinde orta düzeyde bir etkisi olduğu belirlenmiştir.

Araştırmada ayrıca çalışma grubundaki öğrencilerin beceri temelli eleştirel düşünme becerisi öğretimi sürecinde elde ettikleri yansıtıcı düşünme erişi puanlarının 
bazı değişkenlere göre anlamlı olarak farklılaşıp farklılaşmadığı incelenmiştir. Yansıtıcı düşünme becerisinin cinsiyete göre anlamlı farklılaşıp farklılaşmadığını belirlemek için "Mann Whitney-U” testi yapılmıştır. Yapılan analizin sonucu Tablo 3’te verilmiştir.

Tablo 3

Yansitıcı Düşünme Becerisinin Cinsiyete Göre Mann Whitney-U Testi Sonuçları

\begin{tabular}{llllll}
\hline Grup & $N$ & Sira Ortalaması & Sira Toplamı & $\mathrm{U}$ & $p$ \\
\hline Erkek & 32 & 21.98 & 703.50 & \multirow{2}{*}{175.50} & .07 \\
\hline Kadın & 16 & 29.53 & 472.50 & & \\
\hline
\end{tabular}

Tablo 3'teki veriler incelendiğinde yansıtıcı düşünme becerisinin cinsiyet değişkenine göre anlamlı olarak farklılaşmadığı belirlenmiştir. Sıra ortalamalarına bakıldığında kadın deneklerin yansıtıcı düşünme becerilerindeki gelişmenin erkek deneklere göre daha fazla olduğu ancak bu gelişmenin istatistiksel açıdan anlamlı olmadığ 1 ifade edilebilir.

Yansitıcı düşünme becerisinin sosyoekonomik düzeye göre anlamlı farklılaşıp farklılaşmadığını belirlemek için "Mann Whitney-U” testi yapılmıştır. Yapılan analizin sonucu Tablo 4'te verilmiştir.

Tablo 4

Yansıtıcı Düşünme Becerisinin Sosyoekonomik Düzeye Göre Mann Whitney-U Testi Sonuçları

\begin{tabular}{llllll}
\hline Grup & $N$ & Sira Ortalaması & Sira Toplamı & U & $p$ \\
\hline Yüksek & 26 & 27.98 & 727.50 & \multirow{2}{*}{195.50} & .06 \\
\hline Düşük & 22 & 20.39 & 448.50 & \\
\hline
\end{tabular}

Tablo 4'teki veriler incelendiğinde yansitıcı düşünme becerisinin sosyoekonomik düzey değişkenine göre anlamlı olarak farklılaşmadığı belirlenmiştir. Sıra ortalamalarına bakıldığında yüksek sosyoekonomik düzeye sahip öğrencilerin yansitıcı düşünme becerileri düşük sosyoekonomik düzeye sahip öğrencilere göre daha fazla gelişmiştir ancak bu gelişim anlamlı olmamıştır.

Yansıtıcı düşünme becerisinin bir ayda okunan kitap sayısı değişkenine göre anlamlı olarak farklılaşıp farklılaşmadığını belirlemek için "Kruskal Wallis" testi yapılmıştır. Yapılan analizin sonucu Tablo 5’te verilmiştir. 
Tablo 5

Yansıtıcı Düşünme Becerisinin Bir Ayda Okunan Kitap Sayısı Değişkenine Göre Kruskal Wallis Testi Sonucu

\begin{tabular}{llllll}
\hline Grup & $N$ & Sira Ortalamas1 & $S D$ & Ki-Kare & $p$ \\
\cline { 1 - 3 } $0-4$ & 8 & 22.63 & 2 & .181 & .91 \\
\cline { 1 - 3 } $5-9$ & 17 & 25.12 & & \\
\cline { 1 - 3 } 10 ve üstü & 23 & 24.70 & & \\
\hline
\end{tabular}

Tablo 5'teki verilere göre yansıtıcı düşünme becerisinin bir ayda okunan kitap sayısı değişkenine göre anlamlı olarak farklılaşmadı̆̆ı görülmektedir. Sıra ortalamalarına bakıldığında beceri temelli eleştirel düşünme öğretimi sonucunda en çok bir ayda 5-9 kitap okuyan öğrencilerin yansıtıcı düşünme becerisinde gelişim tespit edilmiştir.

Yansıtıcı düşünme becerisinin TV başında günlük geçirilen zaman değişkenine göre anlamlı olarak farklılaşıp farklılaşmadığını belirlemek için "Mann Whitney-U" testi yapılmıştır. Yapılan analizin sonucu Tablo 6'da verilmiştir.

Tablo 6

Yansıtıcı Düşünme Becerisinin TV Başında Günlük Geçirilen Zaman Değişkenine Göre Mann Whitney-U Testi Sonucu

\begin{tabular}{llllll}
\hline Grup & $N$ & Sira Ortalamas & Sira Toplamı & U & $p$ \\
\hline $0-2$ saat & 31 & 23.18 & 718.50 & & \\
\hline 3-5 saat & 15 & 24.17 & 362.50 & & .81
\end{tabular}

Tablo 6'daki verilere göre yansıtıcı düşünme becerisinin TV başında günlük geçirilen zaman değişkenine göre anlamlı olarak farklılaşmadığı görülmektedir. Sıra ortalamalarına bakıldığında beceri temelli eleştirel düşünme öğretimi en çok günde 3-5 saatini TV başında geçiren öğrencilerin yansıtıcı düşünme becerisini geliştirmiştir.

Yansıtıcı düşünme becerisinin bilgisayar, tablet ve akıllı telefon başında günlük geçirilen zaman değişkenine göre anlamlı olarak farklılaşıp farklılaşmadığını belirlemek için "Mann Whitney-U” testi yapılmıştır. Yapılan analizin sonucu Tablo 7'de verilmiştir. 
Tablo 7

Yansıtıcı Düşünme Becerisinin Bilgisayar, Tablet ve Akıllı Telefon Başında Günlük

Geçirilen Zaman Değişkenine Göre Mann Whitney-U Testi Sonucu

\begin{tabular}{lccccc}
\hline Grup & $N$ & Sira Ortalamas & Sira Toplamı & $\mathrm{U}$ & $p$ \\
\hline 0-2 saat & 33 & 26.02 & 858.50 & 131.50 & $.04^{*}$ \\
\hline 3-5 saat & 13 & 17.12 & 222.50 & \\
\hline
\end{tabular}

"p $<.05$

Tablo 7'deki verilere göre yansitıcı düşünme becerisinin bilgisayar, tablet ve akıllı telefon başında günlük geçirilen zaman değişkenine göre anlamlı olarak farklılaştı̆ğ görülmektedir. Sıra ortalamalarına bakıldığında tespit edilen bu anlamlı farklılığın günde 0-2 saat bilgisayar, tablet ve akıllı telefon başında zaman geçiren öğrencilerin lehinde olduğu görülmektedir.

Yansıtıcı düşünme becerisinin interneti kullanma amacı değişkenine göre anlamlı olarak farklılaşıp farklılaşmadığını belirlemek için "Mann Whitney-U” testi yapılmıştır. Yapılan analizin sonucu Tablo 8'de verilmiştir.

Tablo 8

Yansıtıcı Düşünme Becerisinin Interneti Kullanma Amacı Değişkenine Göre Mann Whitney-U Testi Sonucu

\begin{tabular}{lcllll}
\hline Grup & $N$ & Sıra Ortalaması & Sira Toplamı U & $p$ \\
\hline Sosyal Medya/Oyun/Müzik/Video & 21 & 19.81 & 416.00 & 185.00 & $.04^{*}$ \\
\hline Ödev Araştırma & 27 & 28.15 & 760.00 & \\
\hline
\end{tabular}

"p $<.05$

Tablo 8'deki verilere göre yansitıcı düşünme becerisinin interneti kullanma amacı değişkenine göre anlamlı olarak farklılaştığı görülmektedir. Sıra ortalamalarına bakıldığında belirlenen bu anlamlı farklılığın interneti ödev araştırmak için kullanan öğrencilerin lehine olduğu görülmektedir.

Yansıtıcı düşünme becerisinin ders dişı etkinliklere (sanat, müzik, spor vb.) katılım durumuna göre anlamlı farklılaşıp farklılaşmadığını belirlemek için "Mann Whitney-U” testi yapılmıştır. Yapılan analizin sonucu Tablo 9'da verilmiştir. 
Tablo 9

Yansıtıcı Düşünme Becerisinin Ders Dışı Etkinliklere (Sanat, Müzik, Spor vb.) Katılım

Durumu Değişkenine Göre Mann Whitney-U Testi Sonuçları

\begin{tabular}{llllll}
\hline Grup & $N$ & Sira Ortalamas & Sira Toplamı & U & $p$ \\
\hline Evet & 26 & 24.92 & 822.50 & 233.50 & .75 \\
\hline Hayır & 22 & 23.57 & 353.50 & & \\
\hline
\end{tabular}

Tablo 9'daki veriler incelendiğinde yansıtıcı düşünme becerisinin ders dış1 etkinliklere (sanat, müzik, spor vb.) katılım durumuna göre anlamlı olarak farklılaşmadığı belirlenmiştir. Sıra ortalamalarına bakıldığında ders dışı etkinliklere (sanat, müzik, spor vb.) katılanların yansıtıcı düşünme becerileri uygulama sürecinde katılmayanlara göre daha fazla gelişmiştir ancak bu gelişim anlamlı olmamıştır.

\section{Sonuç ve Tartışma}

Araştırmada öğrencilerin eleştirel düşünme öğretim programının uygulanmasının yansıtıcı düşünme becerilerinde anlamlı bir farklılık oluşturup oluşturmadığ1 belirlenmeye çalışılmıştır. $\mathrm{Bu}$ yolla eleştirel düşünme öğretim programının öğrencilerin yansıtıcı düşünmesine yaptığı etkiyi belirlemek amaçlanmıştır.

Yapılan analizler sonucunda beceri temelli eleştirel düşünme öğretiminin uygulandığı öğrencilerin öğretim öncesi ve sonrasında yansıtıcı düşünme becerisi ölçeğinden aldıkları puanlar anlamlı bir farklılık göstermektedir. Etki analizi ile bu değişimde programın orta düzeyde etkili olduğu belirlenmiştir. Böylece süreç içinde öğrencilerin hem karşılaştıkları olay, olgu, durum, problem ve sorulara ilişkin sahip oldukları görüşün sorumluluğunu alma hem de tüm öğretim süreci üzerinde değerlendirici bir bakışla güçlü ve zayıf yönlerini belirleme noktalarında bir ilerleme göstermişlerdir. Öğrenciler eleştirel düşünme öğretim programındaki etkinlikler bağlamında karşılaştığı problemlere dair sürecin başında tek bir doğru çözüm üretebilirken, sürecin sonuna doğru arkadaşlarının görüşlerini de değerlendirerek çoklu çözümlere ulaşma becerisi göstermişlerdir. Bununla birlikte sürecin sonunda hem düşünme süreçlerini hem de bu süreç sonundaki ürünü değerlendirme yetilerinin arttığı söylenebilir.

Düşünmenin özel bir çeşidi olan yansıtıcı düşünme; şüphe, tereddüt, karışıklık ile bu karışıklığı çözmek için araştırma ve sorgulama yapmayı içermektedir. Yansıtma sürecine bu karışıklığı çözme isteği rehberlik eder (Rodgers, 2002). Taggart ve Wilson (1998) yansıtıcı düşünmeyi eğitim sorunları üzerinde mantıklı kararlar alma süreci ve sonra alınan kararların değerlendirilmesi olarak tanımlamıştır. Bu çalışmada öğrenciler eleştirel düşünme öğretimi sürecinde fikirlerini serbestçe ifade etmişler ve bu fikirlerini veya çıkarımlarını kanıtlar temelinde savunmuşlardır. Bazı durumlarda farklı görüşe sahip arkadaşları ile fikirleri müzakere sürecine girmişler ve düşüncelerinin sorumluluğunu alarak kendi görüşlerini nedenlere dayandırarak karşı tarafı ikna etmeye çalışmışlardır. Bazen ise kanıtların karşıt görüşün doğruluğunu işaret ettiğini fark ederek kendi görüşlerini revize etme yoluna gitmişlerdir. 
Wilson ve Jan (1993)'ın belirttiği üzere yansıtıcı düşünme; eleştirel düşünme, yaratıcı düşünme, biliş ötesi düşünme ve problem çözme becerilerini kapsamaktadır. Eleştirel düşünme, özel bir düşünce alanına ilişkin kusursuz düşünceyi ortaya çıkaran disiplinli ve özdenetimli düşünme şeklidir. Ennis (1986)'in “eleştirel düşünme bireyin ne yapacağına ya da neye inandığına karar vermeye odaklanan yansıtıcı düşünmedir" tanımı yansıtıcı düşünmenin kapsamında eleştirel düşünmenin bulunduğuna işaret etmektedir (aktaran, Semerci \& Yanpar-Yelken, 2010). Yansitıcı düşünme, eleştirel düşünme ile bağlantılıdır. Çünkü her iki düşünme becerisi de sorgulama ve değerlendirme, düzenleme, mantık yürütme, varsayım ve tahmini içerir (Wilson \& Jan, 1993). Bu nedenle bir kişi eleştirel düşünürken aynı zamanda yansıtıcı da düşünür. Bu çalışma özelinde eleştirel düşünme öğretimine ilişkin bir sürecin öğrencilerin yansıtıcı düşünme becerilerinde de gelişim sağlaması literatürdeki bu açıklamaları uygulama anlaminda desteklemektedir.

Weast'1n (1996) yansıtıcı düşünme becerisini oluşturan alt becerilere ilişkin listesi bu çalışmada da eleştirel düşünmenin alt becerileri listesindeki becerilerle örtüşmektedir. Örneğin sebepler ve kanıtları belirlemek, mantıksal gerekçelendirmeleri yani çıkarımları değerlendirme, belirtilmeyen bilgiyi de karar verirken göz önüne alma gibi becerileri her iki düşünme becerisinin de kapsamına giren becerilerdir. Norton (1994) da yansıtıcı düşünen öğretmen ve öğrencilerin; amaçlarını devamlı şekilde sorgulayan, uygulamalarının sonuçlarını takip eden, kısa ve uzun vadeli düşünebilen, değerlendirme yaparken diğerlerinin görüşlerini de dikkate alan bireyler olduğunu ve bu anlamda eleştirel bir düşünür özelliği de gösterdiklerini belirtmiştir. Özensoy (2011) da eleştirel bir okuma için okunanlardan elde edilenlerin yargılanması, sorgulanması, değerlendirilmesi ve güvenilir kaynaklar ve akıl yürütme ile bir sonuca varılması gerektiğini belirtmektedir. $\mathrm{Bu}$ bağlamda eleştirel okuma yapabilmek için aslında edinilen bilgi birimlerine ve deneyimlere eleştirel bir bakışı ifade eden yansıtıcı düşünme becerisine de sahip olmak gerektiği ifade edilmiştir. Bu bağlamda araştırmada eleştirel düşünme becerisini geliştirmeye yönelik gerçekleştirilen sürecin, öğrencilerin yansıtıcı düşünme becerisinde de bir gelişimi sağlaması, alanyazında bu iki beceri arasında bulunan yakın ve karşılıklı ilişkinin ifade edilmesini destekler niteliktedir.

Literatürde de eleştirel ve yansıtıcı düşünme becerilerinden herhangi birini geliştirmeye dönük uygulamaların, diğer beceri üzerinde de olumlu etkiye sahip olduğunu belirleyen çalışmalar mevcuttur. Griffin (2003) yaptığı çalışmada eleştirel olayların kullanıldığı beceri temelli ve koçluğu da içeren denetimli bir alan deneyiminin öğretmenlerin eleştirel ve yansıtıcı düşünme becerilerini geliştirdiğini belirlemiştir. Eleştirel olaylar yazma ve bunları inceleme etkinliklerinin öğretmenlerin Dewey (1933; aktaran Griffin, 2003)'in ifade ettiği yansıtıcı düşünmenin üç boyutunda -açık fikirlilik, sorumluluk ve içtenlik- gelişime neden olduğu belirlenmiştir.

Chi (2010) yaptığı araştırmada, yansıtıcı düşünme etkinlikleri içeren bir öğretim programı sonunda 20 adet öğretmenden günlük tutma ve görüşme yoluyla veri toplamıştır. Bu veriler yardımıyla öğretmenlerin yansıtmayı ne düzeyde kullandıkları ve yansıtmanın öğretimsel değerine ilişkin algıları belirlenmeye çalışılmıştır. Araştırma sonucunda öğretmenlerin yansıtma becerilerinin gelişimi sonucu çeşitli bağlamlardaki 
belirsizlik, kararsızlık ve değer çatışması durumlarında daha yetkin davrandıkları belirlenmiştir. Bununla birlikte öğretimsel verimliliğe ilişkin farkındalığ 1 arttırmanın yanı sıra, gerçekleştirilen öğretimin öğretmen ve öğrenen olarak eleştirel düşünme becerisini de geliştirdiği tespit edilmiştir.

Saçlı (2013) yaptığı çalışmada yansıtıcı öğrenci günlüklerinde, yaratıcı drama eğitimi alan grubun dönem başları ve sonlarında derslerde karşılaştıkları düşünsel zorluklar ve üretilen mantıklı çözümler arasında eleştirel düşünmenin baskın şekilde yer alan bir bileşen olduğunu ve bunun dönem ortalarında yerini grup çalışmalarına bıraktığını belirlemiştir. Bununla birlikte, eleştirel düşünmenin dönem başından sonuna kadar düşünsel kaynak olarak kullanıldığını ortaya koyarak eleştirel düşünmeye ilişkin olumlu değişimler olduğunu göstermiştir.

Tican (2013) yaptığı çalışmada yansitıcı düşünmeye dayalı öğretim etkinliklerinin, öğretmen adaylarının eleştirel düşünme becerilerine olumlu bir etki yaptığını belirlemiştir. Bu çalışmada da eleştirel düşünme öğretimi içerisinde yansıtıcı düşünmeyi geliştirici stratejiler kullanılmış ve bu durum hem eleştirel düşünme hem de yansıtıcı düşünmede gelişmeyi sağlamıştır.

Elaldı (2013) çalışmasında yansıtıcı düşünme etkinlikleri ile destekli tam öğrenme modelinin uygulandığı deney grubunun ve geleneksel yöntemin kullanıldığ1 kontrol grubunun uygulama öncesi ve sonrasına ait eleştirel düşünme puanlarının farklılaşmadığını belirlemiştir. Üniversite öğrencileri üzerinde yapılan çalışmada yansıtıcı düşünme etkinlikleriyle destekli tam öğrenme modelinin kullanılması, her iki grubun eleştirel düşünme puanları üzerinde olumlu etki göstermemiş; gruplar arasında da eleştirel düşünme puanları açısından anlamlı bir farklılık göze çarpmamıştır. Bu noktada eleştirel düşünmenin yansıtıcı düşünme için bir ön koşul olarak kabul edilebileceği veya yansıtıcı düşünmeyi de içine alan daha kapsamlı bir düşünme becerisi olduğu ifade edilebilir. Bu nedenle yansıtıcı düşünme becerisini bu çalışmada olduğu gibi eleştirel düşünme becerisine dönük bir programla geliştirmenin daha olumlu sonuçlar vereceği belirtilebilir.

Aktaş (2016) yaptığı çalışmada 400 lisans öğrencisi üzerinde yaptığ çalışmada öğrencilerin yansıtıcı düşünme eğilimleri ile eleştirel okuma özyeterlik algıları arasında bir ilişki olup olmadığını belirlemeye çalışmıştır. Araştırma sonuçlarına göre öğrencilerinin eleştirel okuma özyeterlik algısı ve yansıtıcı düşünme puanları arasında düşük ama anlamlı düzeyde bir ilişki vardır. Bu bulgular araştırmanın sonuçlarıyla paralellik göstermektedir.

Araştırmada ayrıca deney grubundaki öğrencilerin beceri temelli eleştirel düşünme öğretimi sürecindeki yansıtıcı düşünme erişi puanları cinsiyet, sosyoekonomik düzey, bir ayda okunan kitap sayısı, TV başında geçirilen günlük zaman ve ders dışı etkinliklere katılım durumuna göre anlamlı farkl11ık göstermezken bilgisayar, tablet ve akıllı telefon başında geçirilen günlük zaman, interneti kullanma amacı değişkenlerine göre anlamlı olarak farklılaşmıştır. Buna göre bilgisayar, tablet ve akıllı telefon başında günlük geçirdiği zaman 2 saatin üzerinde olmayan ve interneti boş zaman etkinlikleri için değil de ödev ve araştırma için kullanan 5. sınıf öğrencilerinin yansıtıcı düşünme becerilerindeki gelişme anlamlı olarak daha yüksek gerçekleşmiştir. Bu bulgudan 
hareketle özellikle günümüzde sosyal medyayı takip etmek için kullanılan bilgisayar, tablet vb. araçların öğrenciler için yansıtma becerileri bağlamında olumsuz bir etkiye sahip olduğu ifade edilebilir. İnternet ve internete erişimi mümkün k1lan bu araçların bireyin genel anlamda düşünme ve akıl yürütme özelde ise kendi deneyimlerini eleştirel olarak analiz ettiği yansıtıcı düşünme yetilerinin gelişimine negatif etki yaptığı söylenebilir.

Demirbaş (2012) ilköğretim 4. ve 5. sınıf öğrencilerinin yansıtıcı düşünme beceri düzeyleri ile öğretmenlerinin alternatif ölçme-değerlendirme tekniklerini bilme ve tercih etme sıklıkları arasındaki ilişkiyi ortaya koymayı amaçlayan bir çalışma yapmıştır. Araştırma sonunda ilköğretim 4. ve 5. sınıf öğrencilerinin yansıtıcı düşünme beceri düzeylerinin yüksek olduğu, cinsiyete göre kız öğrenciler lehine anlamlı bir şekilde farklılaşmaktayken; sınıf düzeyine göre farklılaşmadığı belirlenmiştir. Cinsiyete ilişkin bulgu bu çalışmanın bulguları ile farklılık arz etmektedir. Bunun çalışmaların modellerindeki farklılıktan kaynaklandığı ifade edilebilir.

Şahin (2011)'in gerçekleştirdiği çalışmanın amacı, Türkçe öğretmeni adaylarının yansıtıcı düşünme eğilimlerini cinsiyet ve sınıf değişkenlerine göre değerlendirmektir. Araştırmanın çalışma grubunu Atatürk Üniversitesi Kâzım Karabekir Eğitim Fakültesinde 2009-2010 eğitim-öğretim yılında öğrenim gören, 1. ve 4. sınıf düzeyinde toplam 102 öğretmen adayı oluşturmaktadır. Araştırma sonucunda, dördüncü sınıfta öğrenim gören öğretmen adaylarının yansıtıcı düşünme eğilimlerinin birinci sınıfta öğrenim görenlere oranla daha yüksek düzeyde olduğu; cinsiyet değişkeninin yansitıcı düşünme eğilimine herhangi bir etkisinin olmadığı belirlenmiştir. Cinsiyete ilişkin bulgu bu çalışmanın bulgularıyla paralellik göstermektedir.

\section{Öneriler}

$\mathrm{Bu}$ çalışmada eleştirel düşünme ile yansıtıcı düşünme becerisi arasında ilişki olup olmadığı literatürle de desteklenerek uygulama sürecinde belirlenmeye çalışılmıştır. Bu noktada yansıtıcı düşünmenin teorik çerçevesine ve diğer düşünme becerileri ile ilişkilerini betimlemeye dönük hem teorik hem de uygulamalı çalışmaların sayısı artırılabilir. Bununla birlikte yansıtıcı düşünme becerisi üzerinde anlamlı farklılığa sahip olan değişkelerin belirlenmesi için hem bu çalışmada kullanılan değişkenler hem de bunlara birtakım başka değişkenler eklenerek çalışmalar yapılabilir.

$\mathrm{Bu}$ çalışmanın bulguları 1şı̆̆ında öğrencinin öğrenme sürecindeki deneyimlerini değerlendirebileceği yansıtmaya dayalı süreçlerin öğrenme-öğretme ortamlarında kullanımı genişletilebilir. Nitel ve karma çalışmalar ile yansıtıcı düşünme becerisini geliştiren öğrenme ortamlarının ne gibi özelliklere sahip olması gerektiği belirlenebilir. 


\section{Summary}

Purpose and Significance: Critical thinking is, in its most general form, to assess the level of rationality, validity or correctness of expressions or to assess to what extent a result is reasonable or proven. Reflective thinking, on the other hand, is critical thinking, problem identification and solving, and consequently restructuring of future thoughts on experience acquired or actualized by an action. From this point of view, critical thinking and reflective thinking are sometimes intertwined skills that can be used in the same sense, and the individual must be able to think critically first so that he can reflectively think. Because an individual reflecting on his/her own experience will critically examine all phenomena and processes related to these experiences and will analyze these facts and processes and arrive at the examined judgments about them. Besides, a basic prerequisite for critical thinking is that the individual is aware of his own thinking process and that he can develop a logical measure to monitor and evaluate his/her thinking process and to take responsibility for the process. Reflective thinking is a priority skill that an individual who carries out the process of critical thinking must apply to increase the quality of this process and to increase the likelihood of achieving the desired result.

In this context, it is the main problem of the research to determine whether the implementation of skills-based curriculum design of critical thinking skill causes a significant difference in reflective thinking skills of $5^{\text {th }}$ grade students. However, whether the level of reflective thinking skills of $5^{\text {th }}$ grade students show a meaningful difference according to gender, socioeconomic level, the number of books read per month, the time spent on TV, the time spent on the computer, tablet and smart phone, purpose of using internet and participation in extracurricular activities (art, music, sports, etc.) variables determined as the sub-problem of the research and it was aimed to make a contribution to the literature about the factors affecting the development of reflective thinking skills.

Methods: Experimental design was used in the study. Experimental investigations are intended to test the effect of the differences created by the investigator on the dependent variable. The main purpose in experimental designs is to test the causal relationship between variables. A single group pretest-posttest design was used in this study. Reflective thinking scale was applied to the experiment group before implementation. In the process of training, skills-based teaching process was implemented to the experimental group under the guideline of curriculum design of critical thinking skills. In the skill-based approach, critical thinking instruction is based on a disciplineindependent basis. After the implementation process, the reflective thinking scale was applied once again to the experimental group.

The study group of the research consists of two fifth grade classes in two secondary schools located in Afyonkarahisar city center in 2015-2016 academic year. In order to determine the effect of the socioeconomic level variable on the reflective thinking skill, the two schools in which the application was made were selected from the two different regions of the Afyonkarahisar province as socioeconomic level. The experimental group 
in the school with a high socioeconomic level consists of 26 students, 10 male and 16 female students. The experimental group in the school with a low socioeconomic level consists of 22 students, all male students. In all analyzes except for the analysis of the socioeconomic level variable, these two different groups were considered as one group.

The "Reflective Thinking Scale" developed by Yildirım (2012) under the title of "The Effect of Scientific Process Skills Activities on Elementary School 7th Grade Student's Reflective Thinking" was used to measure the reflective thinking skills of the students. Scale is a likert type scale with 5 items and consists of 17 items. In this study, the Cronbach $\alpha$ reliability coefficient obtained from the preliminary application of the reflective thinking scale was .97 , and the Cronbach $\alpha$ reliability coefficient obtained from the last application was found to be .80 .

Curriculum design of critical thinking is developed by the researcher and consisting of 18 objectives. Considering the skill to be developed in the process of developing the design of the program, it is considered to be a curriculum design reflecting the philosophy of progress and accordingly, the "child-centered design" has been adopted from program design approaches. Within the scope of the program, the strategy of teaching through invention was used. This approach is fundamentally a student-centered approach that allows the student to grasp and reach out to the generalizations on their own.

Results: When the findings of the research are examined it was found that the students who applied the skills-based critical thinking instruction had a significant difference in the scores they got from the reflective thinking ability scale before and after the implementation. In addition to this gain scores that were obtained from reflective thinking skill test of experimental group indicate a statistically significant difference according to daily time spent on computer, tablet and smart phone, purpose of using internet variables. Contrary to this, gain scores did not indicate a statistically significant difference according to gender, socio-economic level, number of books read in a month and participation in extracurricular activities.

Discussion and Conclusions: In the process, students have made progress in determining the strengths and weaknesses of students with an evaluation of the whole teaching process, as well as taking responsibility for their consideration of the events, cases, situations, problems and questions they meet. While the students were able to produce a single correct solution at the beginning of the process for the problems they encountered in the context of activities in the critical thinking curriculum, they were able to reach multiple solutions by evaluating the opinions of their right friends at the end of the process. At the end of the process, however, it can be said that both the processes of thinking and the ability to evaluate the product at the end of this process are increased. 


\section{Kaynakça}

Aktaş, B. Ç. (2016). Pedagojik formasyon programı öğrencilerinin eleştirel okuma özyeterlik algısı ve yansıtıcı düşünme eğilimlerinin incelenmesi. Elektronik Sosyal Bilimler Dergisi, 15(59), 1186-1202. doi: 10.17755/esosder.76856.

Baker, M., Rudd, R. \& Pomeroy, C. (2001). Relationship between critical and creative thinking. Journal of Southern Agricultural Education Research, 51(1), 173-188.

Beyer, B. (1995). Critical thinking. Indiana: Phi Delta Kappa Educational Foundation.

Büyüköztürk, Ş., Kılıç Çakmak, E., Akgün, Ö. E., Karadeniz, Ş., \& Demirel, F. (2012). Bilimsel araştırma yöntemleri. Ankara: Pegem Yayınları.

Chi, F. (2010). Reflection as teaching inquiry: Examples from Taiwanese in-service teachers. Reflective Practice, 11(2), 171-183. doi: 10.1080/14623941003672410.

Choy, S. C. \& Oo, P. S. (2012). Reflective thinking and teaching practices: A precursor for incorporating critical thinking into the classroom. International Journal of Instruction, 5(1), 167-182.

Cohen, J. (1994). The earth is round ( $\mathrm{p}$.05). American Psychologist, 49, 997-1003.

Demirbaş, B. (2012). İlköğretim 4. ve 5. sınıf öğrencilerinin yansıtıcı düşünme beceri düzeyleri ile öğretmenlerinin alternatif ölçme-değerlendirme tekniklerini bilme ve tercih etme sıklıkları arasındaki ilişkinin incelenmesi (Yayımlanmamış yüksek lisans tezi). Marmara Üniversitesi, İstanbul.

Demirel, Ö. (2009). Kuramdan uygulamaya ĕgitimde program geliştirme (Onikinci Baskı). Ankara: Pegem Akademi Yayınları.

Elaldı, Ş. (2013). Yansıtıcı düşünme etkinlikleri ile destekli tam ögrrenme modelinin tıp fakültesi ögrencilerinin üstbiliş becerileri, öz-düzenleme stratejileri, öz-yansitma becerileri, öz-yeterlik inançları, eleştirel düşünme becerileri ve akademik başarılarına etkisi (Yayımlanmamış doktora tezi). Fırat Üniversitesi, Elazı̆ğ.

Elder, L. \& Paul, R. (2004). Critical thinking and the art of close reading (part IV). Journal of Developmental Education, 28(2), 36-37. Retrieved from http://files.eric.ed.gov/fulltext/EJ718574.pdf.

Ennis, R. H. (2011). The nature of critical thinking: An outline of critical thinking dispositions and abilities. Paper presented at 6th International Conference on Thinking at MIT, Cambridge, http://faculty.education.illinois.edu/rhennis/documents/TheNatureofCriticalThinkin g_51711_000.pdf sitesinden 11 Eylül 2014 tarihinde alınmıştır.

Ennis, R. (1997). Incorporating critical thinking in the curriculum: an introduction to some basic issues. Inguiry: Critical Thinking Across the Disciplines, 16(3), 1-9. Retrieved from http://faculty.education.illinois.edu/rhennis/documents/IncorpY400dpiBWNoDrop Pp1-9PrintD.pdf. 
Ennis, R. (1989). Critical thinking and subject specificity: Clarification and needed research. Educational Researcher, 18(3), 4-10.

Epstein, R. L. \& Kernberger, C. (2006). Critical thinking (Third Edition). Canada: Thomson Wadsworth.

Facione, P. A. (1990). Critical thinking: A statement of expert consensus for purposes of educational assessment and instruction - executive summary - the Delphi report. Millbrae, CA: The California Academic Pres. ERIC Document Reproduction Service No. ED 315 423. http://ericir.syr.edu sitesinden 21 Eylül 2014 tarihinde alınmıştır.

Gelter, H. (2003). Why is reflective thinking uncommon. Reflective Practice, 4(3), 337345. Retrieved from https://www.divaportal.org/smash/get/diva2:978213/FULLTEXT01.pdf.

Griffin, M. (2003). Using critical incidents to promote and assess reflective thinking in preservice teachers. Reflective Practice, 4(2), 207-220. doi: $10.1080 / 14623940308274$.

Halpern, D. F. (1996). Thought and knowledge: an introduction to critical thinking (3rd ed.). Mahwah, NJ: L. Erlbaum Associates.

Karacaoğlu, Ö. C. (2011). Online eğitimde program geliştirme. Ankara: İhtiyaç Yayıncilık.

Kılıç, S. (2014). Etki büyüklügü. Journal of Mood Disorders, 4 (1), 44-6

King, P. M. \& Kitchener, K. S. (1994). Developing reflective judgment: Understanding and promoting intellectual growth and critical thinking in adolescents and adults. San Francisco: Jossey-Bass.

Kurnaz, A. (2013). Eleştirel düşünme öğretimi etkinlikleri planlama-uygulama ve değerlendirme. (2. Baskı). Konya: Eğitim Kitabevi.

Mason, M. (2008). Critical thinking and learning. USA: Blackwell Publishing.

Moon, J. (2008). Critical thinking: An exploration of theory and practice. London and New York: Routledge.

Norton, J. L. (1994). Creative thinking and locus of control as predictors of reflective thinking in pre-service teachers. Paper presented at the Annual Meeting of the Association of Teacher Educators (74th, Atlanta, GA, February 12-16, 1994). Retrieved from http://files.eric.ed.gov/fulltext/ED366579.pdf.

Özensoy, A. U. (2011). Eleştirel okumaya göre düzenlenmiş sosyal bilgiler dersinin eleştirel düşünme becerisine etkisi (Yayımlanmamış doktora tezi). Gazi Üniversitesi, Ankara.

Paul, R. \& Elder, L. (2013). Kritik düşünce (Esra Aslan \& Gamze Sart Çev.). Ankara: Nobel Yayınları. 
Rodgers, C. (2002). Defining reflection: another look at John Dewey and reflective thinking. Teachers College Record, 104(4), 842-866. Retrieved from http://www.bsp.msu.edu/uploads/files/Reading_Resources/Defining_Reflection.pdf

Ross, D. D. (1989). First steps in developing a reflective approach. Journal of Teacher Education, 40(2), 22-30. doi: 10.1177/002248718904000205

Ruggerio, V. R. (2011). Beyond feelings: a guide to critical thinking (Ninth Edition). New York: McGraw-Hill.

Saçlı, F. (2013). Yaratıcı drama ĕgitiminin aday beden ĕgitimi öğretmenlerinin eleştirel düşünme becerileri ve eğilimleri üzerine etkisi (Yayımlanmamış doktora tezi). Hacettepe Üniversitesi, Ankara.

Semerci, N. (2000). Kritik düşünme ölçeği. Eğitim ve Bilim, 25(116), 23-27. http://egitimvebilim.ted.org.tr/index.php/EB/article/download/5275/1438 adresinden alınmıştır.

Semerci, N. \& Yanpar Yelken, T. (2010). İlköğretim programlarındaki ortak temel becerilere ilişkin öğretmen görüşleri (Elazığ ili örneği). Doğu Anadolu Bölgesi Araştırmalarl, $\quad$ 8(2), 47-54. $\quad$ http://web.firat.edu.tr/daum/default.asp?id=99 adresinden alınmıştır.

Şahin, A. (2015). Öğretim ilke ve yöntemleri. G. Ocak (Ed.) içinde Temel öğretmeögrenme yaklaşımları (stratejiler). (ss. 214-257). Ankara: Pegem Akademi Yayıncilik.

Şahin, A. (2011). Türkçe öğretmeni adaylarının yansıtıcı düşünme eğilimlerinin çeşitli değişkenlere göre değerlendirilmesi. Elektronik Sosyal Bilimler Dergisi, 10(37), 108-119. http://dergipark.gov.tr/download/article-file/70293 adresinden alınmıştır.

Taggart, G. L. \& Wilson, A. P. (1998). Promoting reflective thinking in teachers 44 action strategies. California: Corwin Press.

Tican, C. (2013). Yansıtıcı düşünmeye dayall öğretim etkinliklerinin öğretmen adaylarının yansitıcı düşünme becerilerine, eleştirel düşünme becerilerine, demokratik tutumlarına ve akademik başarılarına etkisi (Yayımlanmamış doktora tezi). Gazi Üniversitesi, Ankara.

Ünver, G. (2003). Yansıtıcı düşünme. Ankara: Pegem A Yayıncılık.

Weast, D. (1996). Alternative teaching strategies: The case for critical thinking. Teaching Sociology, 24, 189-194. Retrieved from https://www.jstor.org/stable/1318809?seq=1\#page_scan_tab_contents.

Wilson, J. \& Jan, L. W. (1993). Thinking for themselves developing strategies for reflective learning. Australia: Eleanor Curtain Publishing.

Yıldırım, C. (2012). Bilimsel süreç becerileri etkinliklerinin ilköğretim 7. Sınıf ögrencilerinin yansıtıcı düşünmelerine etkisi (Yayımlanmamış yüksek lisans tezi). Pamukkale Üniversitesi, Denizli. 
Yüksel, S. (2007). Bilişsel alanın sınıflamasında (taksonomi) yeni gelişmeler ve sinıflamalar. Türk Ĕ̌gitim Bilimleri Dergisi, 5(3), 479-509.

Yıldırım, H. H. \& Yıldırım, S. (2011). Hipotez testi, güven araliği, etki büyüklüğü ve merkezi olmayan olasilik dağilimlari üzerine. İlkögretim Online, 10, 1112-23. 